\title{
The Dark Side of Tobacco Industry's CSR: A Socio-Legal Analysis of the Indonesian Corporate Hegemony Campaign
}

\author{
Auditya Firza Saputra* \\ University of Indonesia, Indonesia
}

\begin{abstract}
As the only country in the Asia-Pacific region that has not yet accessed the Framework Convention on Tobacco Control (FCTC), Indonesia faced an alarming smoking prevalence rate. The situation has worsened during the COVID-19 outbreak because excessive tobacco smoking behavior increased people's health vulnerability. Despite the destructive impact, most Indonesian citizens shared a common belief about the tobacco industry's importance to the economy. This paper aimed to seek the primary legal issue to reveal how the hegemony latently operated. It deconstructed the established dogma about the industry's misperceived social reputation that frequently served as justifications favoring the industry. Narratives on economic contribution and the industry's philanthropic campaigns displayed the industry as the protagonist sector and played a significant role in creating a false public opinion on the tobacco industry's reputation. Using a qualitative socio-legal approach, this paper critically described how the industry used the hegemonic methods manifested in Corporate Social Responsibility (CSR) campaigns, which contradicted the ethical principle to secure its market dominance. As a result, the partial legal approach to tobacco control regarding CSR encountered minimalist market interventions from the government, which emerged as the main causes of such an anomaly. As the tobacco control challenge predictably got more difficult on the verge of an economic downturn, the urgency of accessing the FCTC was highly crucial to saving citizens from the upcoming demographic calamity.
\end{abstract}

KEYWORDS: Tobacco Industry, Business and Human Rights, Corporate Hegemony.

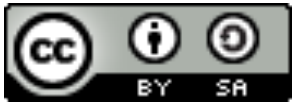

HOW TO CITE:

Saputra, Auditya Firza, "The Dark Side of Tobacco Industry's CSR: A Socio-Legal Analysis of the Indonesian Corporate Hegemony Campaign" (2021) 2:1 Indonesian Journal of Law and Society 1-28, online: <https://doi.org/10.19184/ijls.v2i1.21943>.

Submitted: 10/01/2021 Reviewed: 13/01/2021 Revised: 31/01/2021 Accepted: 06/02/2021

\footnotetext{
* Corresponding author's e-mail: audityasaputra@gmail.com
} 


\section{INTRODUCTION}

For quite a long time, the tobacco industry had been known as a vital sector in Indonesia. This industry is not only for creating numerous employment fields, among other excised industry sectors, but also generates up to $96 \%$ of annual revenues to this archipelagic state. ${ }^{1}$ To a certain extent, this paper investigated why the industry is quite popular to the vast majority of Indonesian citizens who frequently perceive the parochial ideas that the industry is merely for promoting significant economic contribution. ${ }^{2}$ With its significant return, however, it came along with the latent risks. Although the contribution narrative might sound favorable to the industry loyal partisans, this phenomenon generated further social consequences. The societal tendency to normalizing the industry's harmful business core suggested a latent example.

As its further implications, Corporate Social Responsibility (CSR) became a popular instrument for big tobacco corporations attracting public endorsement. Backed with substantial financial resources, the industry opportunistically utilized the campaign to portray virtuous narratives into its problematic existence. Hence, such a decorated reputation served the industry actors as social protagonists, despite the inherent destructive impact. However, unlike semiotic studies of tobacco industry advertisement, critical research on the industry's CSR campaign remained unpopular among Indonesian legal scholars. Previous legal studies primarily focused on the legal approach-whether CSR should be mandatory or voluntary. On the other side, because of the altruistic feature, there were no many scholars that openly admitted that the ethical campaign somehow played a significant part in creating the tobacco hegemony. CSR's moral issue in the controversial industry sector, paradoxically, resembled an act of 'doing bad while doing good.'

1 Dwi Hadya Jayani, “Tren Kenaikan Cukai Rokok, 2020 Catat Kenaikan Tertinggi”, online: Databoks Katadata <https://databoks.katadata.co.id/datapublish/2019/09/16/ tren-kenaikan-cukai-rokok-2020-catat-kenaikan-tertinggi>.

2 Ministry of Industrial Affairs, "Gambaran Umum Industri Rokok," online: <https://www.kemenperin.go.id/gambaran-umum-industri-rokok.php>.

3 Ye Cai, Hoje Jo \& Carrie Pan, "Doing Well While Doing Bad? CSR in Controversial Industry Sectors" (2012) 108:4 J Bus Ethics 467-480. 
Scholars like Tandlittin and Luetge revealed that the Indonesian tobacco industry's philanthropic trend contradicted the ethical philosophy of social responsibility. ${ }^{4}$ To some extent, philanthropic CSR was not only an effective soft-selling strategy but also a pseudo-advertising method, an alternative to a shrinking promotion sphere after many limitations made against the marketing rule. As the hegemony involves, the reputation earned from the CSR seemed to work well by often hearing apologetic reasons employed by the partisan to defend the industry despite being linked to many severe societal problems, such as poverty issues and escalating premature deaths. ${ }^{5}$ While the lack of optimum intervention from the authority was the primary reason, this lingering cycle of reputation-making had also become a primary factor in promoting excessive tobacco consuming behavior, which put Indonesia under a threatening level of smoking prevalence situation. ${ }^{6}$ Nevertheless, further on the verge of a worsening pandemic crisis, the concern on prevalence level attracted greater attention from the global community.

Recent research revealed causal correlations of smoking habits to the increasing of COVID-19 fatality risks. ${ }^{7}$ It argued that the long-term tobacco smoking habit multiplies the death risk of the patient. The bigger smoker population one country obtained simultaneously generates more vulnerability to the people. To some extent, the finding self-explained the unspoken reason behind the very high death cases ratio in the nation, as the country was named among the biggest smoker populations in the world. ${ }^{8}$ The threat encouraged criticisms against the government's commitment to

4 Harsman Tandilittin \& Christoph Luetge, "CSR Activity of Tobacco Companies in Indonesia: Is it a genuine social responsibility?" (2015) 11 OJHE, online: <http:// aquila.usm.edu/ojhe/vol11/iss1/3>.

5 Indonesian Statistics Bureau, Profil Kemiskinan di Indonesia Tabun 2019, No. 56/07/ Th.XXII (Jakarta: Badan Pusat Statistik, 2020).

6 Richard D Hurt et al., "Roadmap To A Tobacco Epidemic: Transnational Tobacco Companies Invade Indonesia" (2012) 21:3 Tob Control 306-312.

7 Roengrudee Patanavanich \& Stanton A Glantz, "Smoking Is Associated With COVID19 Progression: A Meta-analysis" (2020) 22:9 Nicotine Tob Res 1653-1656.

8 The Jakarta Post, "Smokers in Indonesia are at high risk for COVID-19': WHO", online: The Jakarta Post <https://www.thejakartapost.com/life/2020/03/14/smokersin-indonesia-are-at-high-risk-for-covid-19-who.html> . 
lowering the smoking prevalence level. In such a view, the number of fatal cases could have been reduced and the the government was more mindful of mending the issue in the first place. However, as the global economic recession arrives, the future of Indonesia's tobacco control remained uncertain. Predictably, the economic downturn forced the authority to take any opportunist option to recover from the crisis. In such an urgent scenario, the bona fide industry would emerge as a reliable sector to rescue the economy. ${ }^{9}$ Consequently, the government would have limited options other than encouraging more flexible tobacco-market mechanisms, resulting in a massive increase in supply and demand. The scenario would lead to excessive current consumption escalating into demographic calamity.

This paper aimed to seek the legal substance's core issue to reveal how the hegemony latently operated. By doing so, it deconstructed the established dogma about the industry's misperceived social reputation that frequently served as justifications favoring industries. Two questions raise respectively: First, what is the wrong in the existing legal substance that causes the anomaly likely to occur? Second, how do CSR campaigns contribute to creating the hegemony? To answer these primary questions, the paper will contain three sections. The first covers the sociological aspect of hegemony theory and describes how philanthropy campaign hegemonically operates. The second section provides a discursive background on CSR's ethical theory and its normative comparison to the Indonesian anomaly. The last section will elaborate on problems within the existing legal substance.

\section{METHODS}

The paper used a qualitative socio-legal method using a literature review. ${ }^{10}$ Readers are expected to see the critical legal study (CLS) approach and its interdisciplinary analysis with sociology doctrine applied in the paper. The legal materials were sourced from a hard-law instrument such as national

9 Erlangga Djumena, "Secercah Asa di Tengah Ancaman Resesi”, online: Kompas.com $<$ https://money.kompas.com/read/2020/04/25/211100526/secercah-asa-di-tengahancaman-resesi>.

10 Reza Banakar \& Max Travers, Theory and Method in Socio-legal Research, Oñati International Series in Law and Society (Oxford; Portland, Or: Hart Pub, 2005). 
laws and government regulations; soft-law from international voluntary guidelines, the United Nations Business and Human Rights instruments. The author used secondary data that were collected from previous academic research and other publications in textbooks, journal articles, institutional reports, and online news media platforms, limited to a maximum of seven years backdate. The paper's identified issue served an objective to highlight the misconception and encourage structural change for a better tobacco control policy.

\section{TOBACCO INDUSTRY HEGEMONY}

\section{A. The Unseen Normalization Attempt}

In contrast to most self-autonomy theories, the thesis of hegemony suggests that popular ideas control people's behavior. How humans perceive their reality is influenced by the latent force from surrounding opinions or information that had priorly established. Gramsci views hegemony as a cultural and ideological means whereby the dominant social class influences certain ideological views to gain spontaneous consent from the dominant class. ${ }^{11}$ In short, some versions of the so-called reality were intentionally deployed to maintain social domination.

In laissez-faire, the hegemonic actor was not limited to authority, as Gramsci once believed. Other crucial players like corporations employ a similar method to come into domination. Urban Dictionary offers a more precise casual definition of corporate hegemony:

"corporate influences over the masses as the ultimate goal is to have masses completely stripped of critical thinking so that the masses can be controlled and manipulated like customer puppets." ${ }^{12}$

However, unlike other kinds of power attributed to coercivity, hegemony in action operates through subtle, persuasive approaches. For instance, cultural instruments like pop-culture or mass media exposure. Hegemony occurs

11 Antonio Gramsci, Quintin Hoare \& Geoffrey Nowell-Smith, Selections from the Prison Notebooks of Antonio Gramsci (London: Lawrence \& Wishart, 1971).

12 "Urban Dictionary: Corporate Hegemony," online: Urban Dictionary <https://www. urbandictionary.com/define.php?term=corporate\%20hegemony>. 
subconsciously-without being noticed by the recipients-which for the most part, it works to alleviate, cover the hidden anomalistic aspect of a context. When the tobacco industry is narrated as a beneficial sector to the economy, such a version of reality puts forward an apology towards the growing sentiments or cynicism over the public health concerns. That said, understanding hegemony, therefore, requires knowing and deconstructing how the ideas of reality were intentionally constructed, deployed, and normalized as a common belief in everyday life to appear happening for granted. On its operative aspect, the Italian theorist pointed out two influencing elements of hegemony-in-action, inter alia, the intellectual and moral affection. Wherein this part, the decorated philanthropic act, virtuous reputation, and the glorifying economic narratives serve as the powerful public opinion-making instrument.

\section{Intellectual Influence}

The intellectual sphere from CSR plays a significant role in attracting cognitive recognition. In this context, the affection manifests in (a) the softselling methods using pop-culture exposure; and (b) popular economic narrative that speaks about the industry reputation. Historically, since the emerging global anti-tobacco movement in the 1970s, the polemic of tobacco products' harmful risks put many industry actors in an existential crisis. ${ }^{13}$ The tremendous pressure of losing consumers forced tobacco executives to find better marketing strategies to endure market regression. However, as the unethical business sector lacks any decent description to promote because it contains no actual use-value, the industry adopted a new kind of marketing method to rebrand a better representation to brand image. An example of this intellectual affection frequently appeared in the commodification advertisement technique. By semiotically associating certain cultural constructions such as masculinity, freedom, or nationalism as a representation of the product, the industry can attract a specific consumer

13 Sarah Milov, The Cigarette: A Political History (Cambridge, Massachusetts: Harvard University Press, 2019). 
population who believes it truly expresses the identities. ${ }^{14}$. Here the industry allocates invested big money to hire marketing and communication experts to draw a specific segment of the population by designing the intriguing tobacco advertisement under covert fashion. However, even without displaying the product visually, the promotion can subliminally affect the audience's preferences.

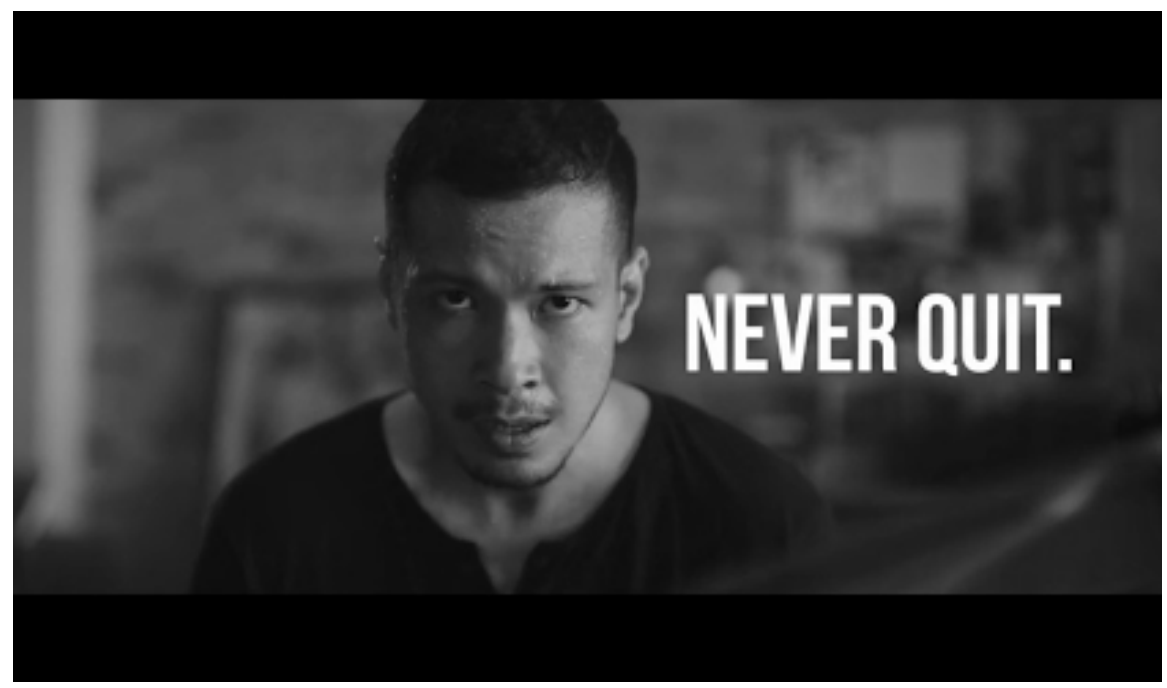

Figure 1. Surya Pro Cigarette 'Never Quit' Commercial

For instance, Gudang Garam’s Surya-Pro “Never Quit” commercial (Figure 1) suggests the semiotic signification among two primary objects: (a) the masculine men image and (b) the 'never quit' which. Semiotically, the subliminal message defines that a genuinely masculine man will never quit (smoking). Similar commodification techniques are used in many other cigarette advertisements broadcasted in contemporary Indonesian media. For example, A Mild has "Go Ahead" and Star Mild has "Ini Baru Laki!". On this aspect, Bourdieu explains that any individuals involved in the market immersed in the symbolic construction, which creates preferences. ${ }^{15}$

Commodification marketing aims to drive consumer interest to purchase the material or use the value of such physical item and the identity construction

${ }^{14}$ Mimi Nichter et al., "Reading Culture from Tobacco Advertisements in Indonesia" (2009) 18:2 Tobacco Control 98-107.

15 Pierre Bourdieu, The Social Structures of the Economy (Cambridge, Malden, MA: Polity, 2005). 
attached to the product or 'extrinsic value'. Due to the intense commodification exposure, the method transformed from merely a marketing attempt to a normalization of the idea that the product truly represents constructed characteristics. ${ }^{16} \mathrm{~A}$ survey made by Tobacco Control Support Centre empirically affirmed that this kind of subliminal advertising effectively persuading youths to perceive that smoking expresses true identity or associating the habit as a typical trend of urban lifestyle. ${ }^{17}$

Furthermore, the other form of cognitive affection in hegemony manifests in the glorifying economic narrative from the tobacco industry; for instance, the excellent role of industry for creating millions of employments or generating significant financial revenue for the state. Quite a contrast with the advertising technique that explicitly targets cigarette consumers' perception, this populist narrative effectively attracts vast majority supportincluding the non-smoker population, as it speaks common interest. The narrative is so powerful that it eventually becomes a means to attract intellectual recognition or legitimacy from the vast public to protect the industry's expansive maneuver. Such a narrative frequently becomes a significant burden to tobacco control effort because any policy made against the industry would have been seen as a dilemmatic effort for juxtaposing the poor tobacco farmers or millions of tobacco labor relying lives on the industry.

The authority, on the other hand, plays a role in affirming the narratives. For instance, as appeared in the following part of these official speeches:

"The development of this industry has become part of the history of our nation and culture, and especially kretek cigarettes, a legacy of our

16 Afdal Makuragga Putra, "Aku Merokok Maka Aku Berpetualang: Konstruksi Pesan dan Resepsi Khalayak Terhadap Iklan-Iklan Rokok Djarum Super Versi Petualangan” in Bunga Rampai Ilmu Komunikasi (Yogyakarta: Litera Press, 2017) 225.

17 Ridwan Fauzi et al., Hubungan Terpaan Iklan, Promosi, Sponsor Rokok dengan Status Merokok di Indonesia (Jakarta: Tobacco Control Support Center \& IAKMI, 2019). 
ancestors and have been rooted for generations," claims Airlangga Hartanto, the Minister of Industry. ${ }^{18}$

Another example is in a response made by President Jokowi when asked why Indonesia has not accessed the Framework Convention of Tobacco Control to date.

"I do not want us (Indonesia) just to join in or follow trends (accessing the FCTC), just because many countries have already joined, which can put many tobacco farmers' lives at stake." ${ }^{19}$

The keywords in italic within the rhetoric were intentionally selected to highlight the industry's protagonist character. Such populist, apologetic attribution drives the vast majority to take such positive attributes as a granted reality. However, such narratives create a certain social symptom, such as defensive gesture, that drives the public to be permissive or misperceive by only setting an eye on the good aspect. The intense exposure from these decorated narratives would create a false consciousness that serves as justification over the risks, which supposedly put into concern in the first place. Finally, this complex cycle of opinion attempts will significantly influence how the public perceives the industry's reputation.

\section{Moral Influence}

Unlike the previous aspect, which captures the cognitive sphere, this part of the hegemonic method aims to influence the moral context. The CSR campaigns have their role: manifested in mostly philanthropic displays like charity giving or education scholarship, the CSR become a vehicle to social capital creation. ${ }^{20}$ Since positive impressions are crucial for this unethical sector, CSR offers them the opportunity to appear, the protagonist, as if the

18 "Kemenperin: Kontribusi Besar Industri Hasil Tembakau Bagi Ekonomi Nasional", online: <https://kemenperin.go.id/artikel/17257/Kontribusi-Besar-Industri-HasilTembakau-Bagi-Ekonomi-Nasional>.

19 Ahmad Nurhasim, "183 Negara Setuju FCTC, Jokowi: Indonesia Jangan Ikutikutan", online: Tempo <https://nasional.tempo.co/read/779728/183-negara-setujufctc-jokowi-indonesia-jangan-ikut-ikutan>.

20 Guido Palazzo \& Ulf Richter, "CSR Business as Usual? The Case of the Tobacco Industry" (2005) 61:4 J Bus Ethics 387-401. 
corporate is socially engaged to the community. In its action, moral affection serves to affect moral consent or impression from the vast majority. ${ }^{21} \mathrm{By}$ conducting philanthropy, the unethical sector changes its look into ethics. As McDaniel \& Malone suggests, tobacco giants use social responsibility campaigns to create the altruistic corporate narrative and rebrand the corporate reputation. ${ }^{22}$ In the Indonesian context, philanthropy often emerges as the best option for the tobacco giants. It is not only for its practicality reason but also because of its high desirability on public perception. Philanthropy touches people personally; thus, the positive impression will be easier to obtain. Culturally, most Indonesian societies tend to prize this kind of behavior as a virtue; hence, the altruist image complements the former economic contribution narrative. In its relations with hegemony, the more personal the affection, the easier it to cast moral legitimacy. Therefore, with such a protagonist impression, the excellent reputation emerged as the alternate representation of the industry existence, covering up the sector's harmful footprints.

Like intellectual affection, the moral influence stimulates the apologetic gesture, as indicated by the tendency to juxtapose the risks with the industry's social contribution. The philanthropy, too, appears as a gestural sign of the industry's social devotion and bona fide. In return, the stakeholder who admires the conduct will prefer the industry to get more protection they deserve in return for social devotion. The thing is that such an excuse often disrupts the critical issue of the danger of the industry. The combination of reputable social and strong financial capital transforms the industry into the too big to fail sector for the country, which explains why many still support the industry despite the high smoking prevalence issue it causes. On this, Saputra suggests the interesting correlation of variables among hegemonic narrative $\left(\mathrm{X}_{1}\right)$, level of criticism $\left(\mathrm{X}_{2}\right)$, to consumer expectation on tobacco

21 Philipp Bachmann \& Diana Ingenhoff, "Legitimacy through CSR Disclosures? The Advantage Outweighs the Disadvantages" (2016) 42:3 Public Relations Review 386394.

22 Patricia A McDaniel \& Ruth E Malone, “What Is Our Story?’ Philip Morris's Changing Corporate Narrative” (2015) 105:10 Am J Public Health e68-e75. 
industry CSR (Y). ${ }^{23}$ His result of studying 79 samples of Jakarta urban smoker population using 49 questionnaire items shows the significance among the acceptance of tobacco industry virtuous narrative and the consumer expectation towards tobacco industry CSR (see Table 1). Interestingly, the research revealed that the more a consumer incline to highly prizes the industry existence as meritorious, the lower would it expect the industry corporation to implement high social responsibility standards.

\begin{tabular}{lllllll}
\multicolumn{1}{l}{ Model } & $\begin{array}{l}\text { Sum of } \\
\text { Squares }\end{array}$ & df & $\begin{array}{l}\text { Mean } \\
\text { Square }\end{array}$ & F & Sig. \\
\hline \multirow{4}{*}{1} & Regression & 2241.978 & 2 & 1120.989 & 28.154 & $.000 \mathrm{~b}$ \\
& Residual & 3065.822 & 77 & 39.816 & & \\
Total & 5307.800 & 79 & & & \\
\hline
\end{tabular}

a. Dependent Variable: $Y$

b. Predictors: (Constant), Total $\mathrm{X}_{2}$, Total $\mathrm{X}_{1}$

Table 1. ANOVA Test Result

The outcome emphasizes CSR's effectiveness for the industry to narrow down the possibility of future liability claims from the consumer. Given these points, CSR's moral impression affirms its role as the best instrument to establish particular ideological views favorable to the tobacco industry's existence. By establishing certain views about the industry's reputation, the tobacco corporation can create a drive towards the market's subconscious preferences and manage to deter any possible market regression and maintain its hegemonic dominance.

23 Auditya Firza Saputra, Self-Control Product as Implementing Instrument for Tobacco Industry Corporate Social Responsibility: A Socio-legal Study (Thesis, Universitas Indonesia, 2020) at 181-192. 


\section{THE ETHICAL ISSUE OF TOBACCO INDUSTRY PHILANTHROPY: FROM PHILANTHROPY TO ETHICAL RESPONSIBILITY}

Some scholars argue that CSR's purpose is to build social engagement through public relations methods, including a defense strategy to counter negative sentiments. In the former view, philanthropy is just among other tools to achieve ends; some might object that corporate philanthropy should be no problem as a social responsibility campaign because it is a voluntary act. This paper should agree with the previous concern, but its essential point is that when unethical businesses like the tobacco industry perform the conduct, the ethical issue eventually emerges.

Philosophically, CSR's basis speaks about the attempt to moralize corporations, as the subject's fictional nature from separate personality often exempted the actor from its social or moral obligations. ${ }^{24}$ The shift from merely corporate's legal obligation to the broad scope of social obligations demands the actor comply with a holistic approach. Its philosophical foundation, therefore, retains a high teleological and deontological virtue ethics. ${ }^{25}$ That means CSR should not merely a ceremonial, formalistic act done by the corporation; the outcome must indeed promote the ethical business transformation for broad stakeholder interests. Criticism against philanthropy as CSR practice often emerges from a belief that such a notion reduces social responsibility quality. Moreover, before getting into the ethical analysis of tobacco industry CSR, we need to discuss the theoretical background to understand why the philanthropic model is no longer relevant to current ethical business progress.

24 Boris Holzer, Moralizing the Corporation: Transnational Activism and Corporate Accountability (Cheltenham, Northampton, MA: Edward Elgar, 2010).

25 Teleological ethics refers to the doctrine of moral theory that requires a concession of one's conduct in its ends and its means. Meanwhile, deontological can be described as a moral theory of one's behavior based on others' moral duty. 


\section{A. Against Tokenistic Form of CSR}

CSR was often seen as a problematic concept until the guiding instrument was proposed. Disagreements on its definition and scope occur out of the multidimensionality aspect of the ethical theory. During the past few decades, theorists have attempted to invent a better, non-tokenistic form of CSR for companies to apply. The traditional philanthropic model, trends that often appear in Indonesian corporate culture, was no longer seen in line with ethical business transformation expectations.

Historically, scholars have invented the 'CSR pyramid' to determine the dimensional value within CSR. Caroll introduced his pyramidal model in which manifested within four levels of social responsibility, inter alia, economic, ethical, legal, and philanthropy in its top-level, ${ }^{26}$ whereas each level reflects a certain quality and public expectation attributed to the corporate existence. Caroll viewed the philanthropic model as the hardest to implement. The company must willingly compromise to allocate some of the shareholder's revenue for a public interest, representing altruistic behavior. However, Caroll's pyramid that placed philanthropy as the ideal social responsibility model has been criticized, notably making CSR merely transactional conduct. Many multinational companies with strong financial resources are inclined to capitalize on the charity event as a call for attention to gain their interest. In the tobacco industry context, the CSR trend often appears as a pseudo-commercial marketing attempt. It promotes the selling of products only in a different, socially altruistic way.

Decades later, Visser, who identified the former theory's anomaly, developed a synthesis with a developing country perspective. ${ }^{27}$ The British scholar argues that the former model is only relevant in American business practices; meanwhile, developing countries have some contrast praxis influenced by specific socio-cultural differences. Caroll's former theory that encouraged

26 Archie B Carroll, "The pyramid of corporate social responsibility: Toward the moral management of organizational stakeholders" (1991) 34:4 Business Horizons 39-48.

27 Wayne Visser, Corporate Social Responsibility in Developing Countries (Oxford University Press, 2009). 
companies to do philanthropy acts produced more social problems than solving them.

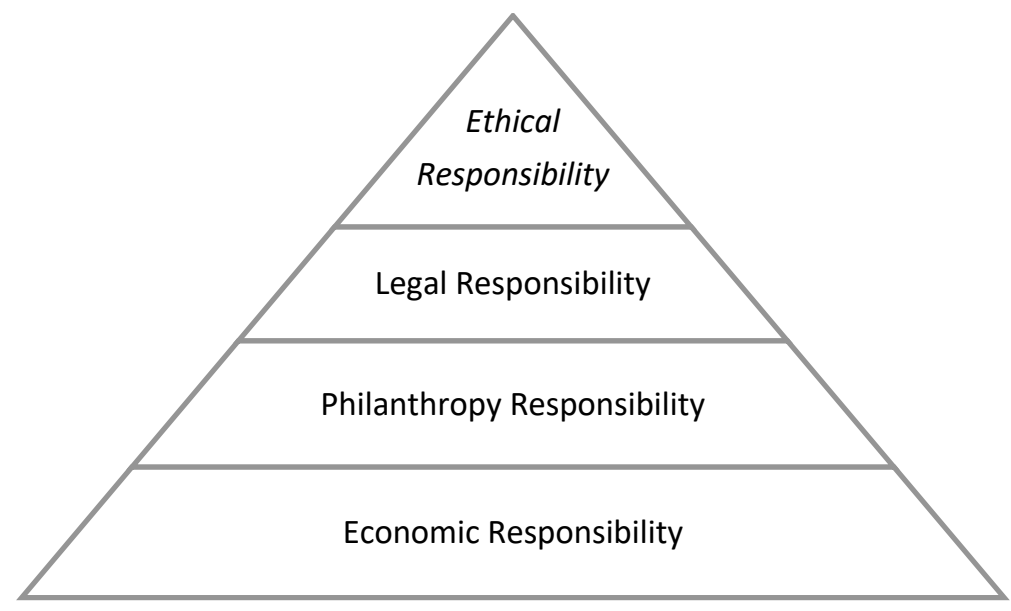

Figure 2. Visser's CSR Pyramid of Developing Countries

Visser gives an example of Africa, where certain communities rely too much on CSR funding from foreign companies. Although the act can buy them a reputation to the company, yet to the community, the practice was far from empowering. Therefore, Visser made adjustments to the hierarchy so that the order becomes economic, philanthropic, legal, and ethical responsibility. ${ }^{28}$ It notes that the difference is in the position of philanthropic

28 Each of the levels can be briefly described as follows:

First, the economic responsibility. It remarks the bottom line to the firm social recognition. Inspired by Friedman's thesis of shareholder primacy principle, Visser emphasizes the primary responsibility of a business firm reflects in its fair profitability. By being economically bona fide, social responsibility resides in the firm's existence and distribution within the economic cycle, for instance, by creating more jobs, paying employees, providing quality goods to society, and sort of things through the market fiscal return mechanism.

Second, the philanthropic responsibility. This dimension suggests the firm be charitable and engage with the community. Despite its higher desirability from the recipient, philanthropy possesses minimum virtue quality for its common excess of creating anomalistic business practices like monopoly, collusion, or dominant position abuse.

Third, legal responsibility. Here the social responsibility reflects in the firm voluntary compliance with all kinds of legal duty and obligations. Presumably, any law-breaking conduct suggests an undermining social commitment of the company. The more the company lingers with legal disputes, the lower the social responsibility representation under such a theoretical perspective.

Fourth and residing at the top of Visser's social responsibility pyramid is an ethical responsibility. Being ethical means performing beyond legal compliance; the firm 
and ethical responsibility. According to Visser, the former tradition is quite problematic in developing countries, while the latter deserves encouragement.

The thesis of ethical responsibility emerges as a foundation to many other recent stakeholder theories of CSR. It implies that CSR's primary duty is to minimize any possible risk and impact that the business activity causes. ${ }^{29}$ The ethical maxim represents 'good as a mean and as an end,' which suggests that the conduct should be performed based on a duty to solve related problems caused by the corporate activities. In contrast, the behavior should be exempted from self-interested motives in its ends. In this view, corporate philanthropy, driven by reputational intentions, does not naturally represent corporate social responsibility's ethical value.

\section{B. Are the Tobacco Industry Philanthropy Campaigns Ethical?}

The tobacco industry trend using CSR has first emerged due to growing sentiments against the tobacco industry, which triggers the advertising restriction policy. Since the 1960s, many authorities in developed countries have issued banning on mass media tobacco product advertisement. The shrinking advertising sphere drove big tobacco companies to find other methods for promoting the product. The CSR eventually emerged as the favored method for its flexibility and capability to create social narratives that help recover the corporate image. History allows us to reveal the anomaly in the CSR practice.

The tobacco industry campaign's problem is that its implementation is somehow unrelated to core problems caused by the industry's existence. For example, when the tobacco industry donates money to a specific social charity event like a scholarship or music event, the conduct has no relevance with the core risks that emerged from the business activity. The genuine CSR

should act all its value creation activity ethically. The firm is expected to take all of its stakeholders' interests into adequate consideration in every business decision.

29 Andrew Crane, Dirk Matten, Laura J. Spence, Corporate Social Responsibility: Readings and Cases in Global Context (London: Routledge, 2008) at 3-20. 
implementation should be performed in line with the duty to minimize impact, which, in this case, the excessive smoking problems resulting from the industry's expansive activity.

Instead of donating money, the primary duty is to raise better consumer awareness on the harmful effect of the product or provide curative medical treatment for nicotine addicts. On this, Tandlittin and Lutge suggest:

“... their (Indonesian tobacco corporations) CSR activities did not provide scientific-based information about the deadly effects of cigarettes on smokers and secondhand smoke on non-smokers. None of the CSR activities disseminated the fact that tobacco-related diseases cause high healthcare costs and that half of the smokers died prematurely. In contrast to public health, the tobacco companies' CSR activities precisely focused on environmental sanitation, blood donation, and rural water supply. These activities are not related to tobacco-related diseases among smokers." ${ }^{30}$

Similarly, the other problem with philanthropy manifestation appears in its inherent 'transactional' nature. The conduct is often misused as a gratification tool to buy out public sympathy-identical to the 'greenwashing' term in the extractive sector. It serves to overthrow the industry's dark footprint. ${ }^{31}$ Such transactional fashion would promote a moral decadency, mostly if the CSR fund recipients were state officialswhich encourage gratification rather than a responsible corporate culture.

Meanwhile, in its ends, the main motive of tobacco industry philanthropy mostly not to be socially responsible; instead, the motive is mainly based on self-interested ends, that is, to secure the market dominancy. In praxis, many precedents indicate decadent reasons for philanthropy as it manifests in the form of a political campaign donation, which generates a conflict-of-interest potency. Frequently, the tobacco money footprints appeared in the donor lists of political candidates contesting the election. ${ }^{32}$ Such patronage attempts to trade influences between the business and the candidate

30 Harsman Tandilittin \& Christoph Luetge, supra note 4.

31 Ye Cai, Hoje Jo \& Carrie Pan, supra note 3.

32 Alfian Putra Abdi, "ICW: Perusahaan Rokok Berpotensi Beri Sumbangan ke Kandidat Pemilu”, online: tirto.id <https://tirto.id/icw-perusahaan-rokok-berpotensiberi-sumbangan-ke-kandidat-pemilu-dcLn>. 
policymaker on upcoming tobacco-related public policies. Similarly, another manifestation of problematic tobacco industry philanthropy resembles community development projects. Rosser suggests that the industry sows its interests by funding civil society organizations or communities to contest the tobacco control campaign. ${ }^{33}$

One apparent precedent indicates in the kretek campaign as cultural heritage narrated by the industry's counterpart. Allegedly funded by the industry, the interest groups produce misinformation articles to agitate anti-tobacco control in popular online platforms. ${ }^{34}$ In this view, by appearing in such a community-based look, the tobacco industry actor can flexibly promote the harmful product without having to worry about breaking the promotion limitation rule. ${ }^{35}$ The manipulating method also generates a pseudo legitimacy, displaying the industry as if it has been supported by society. The cultural propaganda resourced from CSR funding has been many times successful in provoking excellent support, including from many public figures and political actors, even several times proposed in the legislative bill. ${ }^{36}$ From 2014 to 2018, the legislator insisted on proposing a controversial Tobacco Law Bill in a priority list. In its article, the law requires the authority to, instead of issuing stricter restrictions against the expansive market, provide better protection and easier market distribution to kretek tobacco products, which will encourage even worst consumer regeneration. ${ }^{37}$ The conflict of interest and other excesses that appeared in the previous cases should explain why the WHO stood to declare any CSR tobacco industry as inherently contradictive to the ethical foundation of responsible business practice.

33 Andrew Rosser, "Contesting Tobacco-Control Policy in Indonesia" (2015) 47:1 Critical Asian Studies 69-93.

34 For instance, www.komunitaskretek.com or www.bolehmerokok.com.

35 The existing legal substance only covers promotion restriction for the categorized subject of tobacco producer or importer. Therefore, any non-subject might conduct the promotion.

36 "In Its Defense of Kretek as Cultural Heritage, House Warns of 'Foreign Claims,"' online: Jakarta Globe <https://jakartaglobe.id/news/defense-kretek-cultural-heritagehouse-warns-foreign-claims $>$.

37 Indonesian House of Representatives, Naskah Akademik RUU Pertembakauan (Jakarta: Pusat Studi Hukum dan Kebijakan, 2016). 


\section{MAPPING PROBLEMS IN THE EXISTING TOBACCO INDUSTRY CSR REGULATION}

The existing CSR regulation problem emerges from allowing the tobacco industry to conduct CSR under the pseudo-commercial display. However, the legal approach contradicts global tobacco control progress, which encourages a ban on any direct or indirect tobacco commercial, including CSR. With specific adjustments made by the industry, the CSR events ultimately become a soft-selling technique.

The existing Article 36 of Government Regulation No. 109 of 2012 suggests that tobacco companies can perform CSR in the form of sponsorship under these two conditions: (a) not using the trademarked names and logos of tobacco products, including brand images, and (b) not intending to promote tobacco products. ${ }^{38}$ However, the problem is that no apparent difference between sponsorship and CSR except that the law forbids the media coverage for the first, while the latter is allowed. The former description suggests several identifiable problems within the regulation logic.

First, the regulation allows CSR in the form of sponsorship, yet it restricts the promotional intention on the other side. The paradox emerges because the very definition of sponsorship is inseparable from promotional activity. In contrast, Article 1(8) of Government Regulation No. 109 of 2012 defines sponsorship as: "all forms of direct or indirect contributions in the form of funds or otherwise using a variety of activities conducted by institutions or individuals, to exert influence through promotion or use of tobacco products." Emphasizing the objective of sponsorship for promotion interest, CSR in such form inevitably contradictive with non-promotive manner. In this view, never have the industry ever employ non-promotive fashion as long as the sponsorship method allowed. Additionally, the publicity rule suggests the other paradox because enabling the media to cover the CSR, some kind of economic value that the publicity derives will inevitably make the conduct commercial.

38 Government Regulation No. 109 of 2012 on Safeguarding Tobacco Addictive Substances. 
Secondly, in a practical context, the current regulation encourages a motivational shift of social responsibility, from what should have been a genuine ethical commitment to an economic-related purpose. It contradicts the ethical philosophy, but such an excess also drives a tendency to a more CSR transactional model: it promotes a capitalization of social responsibility. As previously stated, such a ceremonialism campaign is not ideal for the industry for diverting the business's awareness of risks. However, the current regulation opens up more possibility to decadency due to the minimalism approach because it contradicts the effort to limit tobacco exposure. Admittedly, allowing such a pseudo-commercial CSR will trigger massive migration from conventional commercial to the latter method. Additionally, it will also contradict the attempt to minimize the sphere of tobacco exposure, which emerges as the primary cause for consumer regeneration.

\section{A. The Price of Minimalist Approach: The Djarum vs. KPAI Polemic}

Because the Government Regulation No. 109 of 2012 only narrowly classifies tobacco industry subjects in its two criteria (the producer and/or the importer), the excluded categories are neither a producer nor an importer, consequently exempted from the subject of this regulation. As a fair comparison, the FCTC approach employs broad categories of parties involved throughout the value chain process, from material suppliers to final marketing agents and the tobacco industry subject. Nobody can perform any kind of promotional campaign that contradicts the law. Due to Indonesia's minimalist subject scope, the industry can easily manipulate the previous CSR requirement in Government Regulation No. 109 of 2012 by arranging separate categorical entities, for instance, a foundation, to conduct pseudocommercial philanthropy. The recent dispute between Djarum Foundation and KPAI (Indonesian Committee for Child Protection) indicates one precedent. ${ }^{39}$

39 Tirto.id, "Audisi PB Djarum Pamit dan Kronologi Polemik yang Picu Teguran KPAI”, online: tirto.id <https://tirto.id/audisi-pb-djarum-pamit-dan-kronologipolemik-yang-picu-teguran-kpai-ehHL >. 
The issue emerged after the Committee summoned Djarum for allegedly performing child objectification for requiring adolescent participants to wear 'Djarum Badminton Club' apparel. However, the rule is clear that no trademark names or logo associated with (United Nations, 2011) tobacco products allowed in any CSR activities. In this case, Djarum argued that they do not violate the rule because the event organizer was a foundation that does not meet the tobacco industry subject's definition.

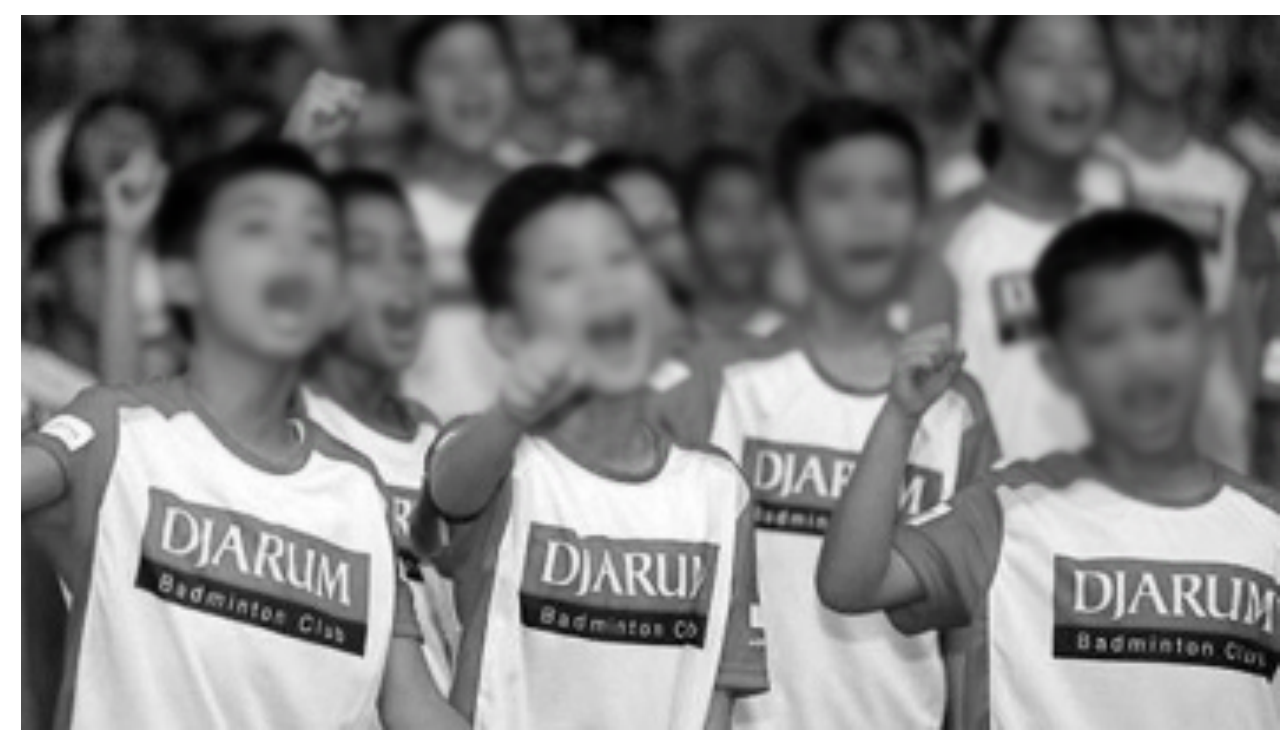

Figure 3. Portrait of Adolescents Participating in Djarum Foundation Sport Audition CSR ${ }^{40}$

Djarum responded to the warning with blackmail to call off their annual audition permanently. Djarum's call immediately attracted huge controversy in social media because seemingly the vast majority did not wish Djarum to stop the audition, which has been famous for its contribution to producing talented local athletes' names. As the media was involved, the polemic quickly escalates, and the Committee, on the contrary, being the one, received vast criticism for problematizing the issue. Even on Twitter, the tagline of \#bubarkanKPAI (disband KPAI) was a trending topic for two days

40 Image Source: https://www.moeslimchoice.com/assets/images/news/2019/09/20190 915120001_normal.jpg 
in a row, signifying that the Committee was instead blamed by the public for the audition's call-off. ${ }^{41}$

Here we can see the anomaly generated by the hegemony from the former case. Although, in this case, Djarum breaches the trademark use restriction, they were free from getting any charge. The law logic employs only the tobacco industry subject, despite no clear distinction on its trademark name and the foundation as the two use the same Djarum name.

Additionally, the case also reveals that Djarum social responsibility's hegemonic influence excellently operates to strip off the mass's critical thinking. Despite the severe violation, the tobacco giant is defended by its partisans to contribute to national sports achievement. However, such an apology is irrelevant and undermining the more substantial problem of child exploitation. Regardless of whom acted as an event organizer, Djarum inevitably received economic benefits from the trademark publication. Furthermore, the hegemonic influence, too, appears in the gesture of the Central Java Governor. Instead of penalizing the action as mandated in Article 38 of Government Regulation No. 109 of 2012, the governor, as expected, turned to back to defend Djarum by glorifying Djarum's virtuous contribution as the justification. ${ }^{42}$

After all, the precedent explains why in many tobacco CSR controversies, holding the suspect liable is a difficult job-facing the company and its partisans created by the hegemony. Such anomaly resulting from the latent encounter of minimalism regulation approach and the hegemonic influence provokes the society's permissive cultural tendencies.

41 Arbi Anugrah, “\#bubarkanKPAI Trending di Twitter, KPAI Angkat Bicara”, online: detiknews <https://news.detik.com/berita-jawa-tengah/d-4698850/bubarkankpaitrending-di-twitter-kpai-angkat-bicara $>$.

42 "Gubernur Jateng Bela PB Djarum Gelar Audisi", online: CNN Indonesia <https://www.cnnindonesia.com/olahraga/20190909153045-170-428802/gubernurjateng-bela-pb-djarum-gelar-audisi>. 


\section{B. The Turn of Business and Human Rights Regime}

One critical question emerges after observing problems in the existing regulations: Can the tobacco industry ever be socially responsible? Over the past decade, international communities initiated numerous attempts to advocate human rights interests into social responsibility instruments. The attempt produces two outcomes, (1) the ISO 26000 on Social Responsibility and (2) the United Nations Guiding Principle on Business and Human Rights. Among the two guiding instruments, the latter become the most referred guiding instrument for internalizing social responsibility practices onto a human rights framework. Despite its voluntary basis, the guiding instrument may offer a better, alternate solution to resolve previous CSR problems emerging from the troubled government regulations.

In line with the arising ethical responsibility concept, the guiding instrument's central thesis suggests that the social responsibility principle's reflective nature should be internalized within daily business activities. In such a perspective, philanthropy does not solely represent valuable social responsibility. Whereas in its foundation, the instrument's articles stipulate that the business firm must perform adequate effort action to protect, in respect to the Civil and Political Rights Covenant and the Economic, and to fulfill the rights in the Covenant of Economic, Social and Cultural Rights sphere. The guiding instrument requires practical to conduct the business firm should comply voluntarily, from actively avoiding harmful excesses, continually identifying impacts, detecting vulnerable groups, and providing adequate remedies based on the former assessment. The firm is also encouraged to employ human rights due to diligence comprehensively to all of its activity. It is from the pre-production to post-consumption while making the assessment result accessible to the public; meaning, as the excess of the tobacco industry, links to many health and societal problems, the guiding human rights parameter should accord with the right to health. Unfortunately, there is no report claiming that the Indonesian tobacco industry ever employed such human rights due to diligence over their business activities. 
Perhaps, the reason comes from the economic aspect that the industry presumably avoided the assessment as it will impose more risks of allocating budget to remedy numerous victims of addiction. The former financial burden, to some extent, explains why the philanthropy primarily addressed to fund unrelated sectors such as education or pop-culture event, instead of health sectors, to draw away the concern about health effects.

\section{Can Tobacco Industry Ever be Socially Responsible?}

Nevertheless, the core human rights issue did not emerge because tobacco companies do not comply with the voluntary human rights assessment. On the contrary, the core human rights problem resides within the harmful industry nature: the products that the industry supplies into the market are medically proven dangerous to consume. ${ }^{43}$ Debates emerged on the topic that splits dualism views.

Despite the product's harmful effect on health, tobacco industry supporters often argue that the tobacco industry did not violate human rights. They claimed that the products were sold in a free market where consumers can exercise free will to decide whether to buy the product. Accordingly, had the health risk eventually emerged, the consumers have admitted consenting to the consequences in the first place. To counter the public health concern, the partisan also highlights the industry's role in creating employments, empowering local farmers, and significantly increasing national income. In this view, the economic benefits contribute to the common welfare. Hence, the tobacco industry's social responsibility towards human rights goals, as the proponent claims, is performed within this cycle.

The opposing groups, however, saw radically different. The former apologetic belief undermines the issue for considering the problem only in a narrow economic paradigm. Regardless of the consumers' right to choose, the addictive product scientifically stimulates physical dependency causing acute addiction to the user. Subliminal marketing attempts covertly

43 World Health Organization, "Tobacco Industry and Corporate Social Responsibility: An Inherent Contradiction" (2004) (WHO Tobacco Control Papers), online: <https://escholarship.org/uc/item/6kf7q7v9>. 
manipulated consumer behavior so that the free will of the consumer exists. Both conditions drive the smokers to buy the product out of irrational wants instead of needs, which explains why the commodity-linked as suspects to poverty problems.

Next, in terms of economic contribution, the cons also reject the myths of the tobacco industry's advantages. Given the adverse socio-cultural consequences, the cons reveal that the aftermath of the excessive smoking phenomenon is causing more economic damage than it generates. The Ministry of Health reported the immaterial loss caused by the smoking fever was up to Rp4,180 trillion, or nearly one-third of the Nation's Gross Domestic Product (GDP) ${ }^{44}$; yet not to mention the material loss linked to the excessive smoking habit, which led to the health sector deficits caused by the medical bill overclaims. This projection strongly falsifies the proponent's claims on economic advantages. Instead of solving the problems, the industry's presence is causing even more social issues. From a human rights perspective, the unethical business does not deserve the socially responsible predicate. Its very own business core contradicts the human rights ends. Simultaneously, retaining the toxic relationship between the government and the tobacco industry should indicate an omission of the state's obligation to protect and fulfill public health as a fundamental human right.

\section{CONCLUSION}

CSR plays a crucial role in constructing the tobacco industry hegemony. The problem resulted from the accumulation of both existing legal and social issues. First, the CSR anomaly emerges due to a misconception in the existing Government Regulation No. 109 of 2012 on Safeguarding Tobacco Addictive Substances. The flexible publicity rule allows the tobacco industry to capitalize CSR campaigns as an alternative commercial method, saving them from the shrinking sphere of advertising. Additionally, the current regulation only covers a minimalistic category of the tobacco industry so that

44 Indonesian Ministry of Health, Perilaku Merokok Masyarakat Indonesia: Berdasarkan Riskesdas Tahun 2007-2013 (Jakarta: Pusat Data dan Informasi Kemenkes, 2013). 
it does not reach the CSR practice done by non-categorized tobacco industry affiliation's entity.

Secondly, in the social context, the hegemony works by normalizing tobacco industry domination's status quo. Grand narratives on the tobacco industry's economic contribution and social responsibility work subconsciously to influence the public sentiment to favor the industry despite the severe societal damages the industry sector has produced. Ethically speaking, the tobacco industry philanthropy campaigns contradict the ethical dimension of social responsibility. The notion is not in line with its duty to remedy risks caused by its harmful products. An adequate backup from the global community is required to counter the established dogma from tobacco industry hegemony. Accessing FCTC should be a taken option to get out of the lethal hegemony and prevent the worsening demographic catastrophe. The FCTC instrument can help Indonesia overcome the situation since it offers a better, holistic approach throughout four spheres of issues: the legal substance, economical approach, health sector, and political sphere.

\section{REFERENCES}

Abdi, Alfian Putra. "ICW: Perusahaan Rokok Berpotensi Beri Sumbangan ke Kandidat Pemilu", online: tirto.id <https://tirto.id/icw-perusahaanrokok-berpotensi-beri-sumbangan-ke-kandidat-pemilu-dcLn>.

Anugrah, Arbi. "\#bubarkanKPAI Trending di Twitter, KPAI Angkat Bicara”, online: detiknews <https://news.detik.com/berita-jawatengah/d-4698850/bubarkankpai-trending-di-twitter-kpai-angkatbicara>.

Banakar, Reza \& Max Travers, eds. Theory and Method in Socio-legal Research, Oñati International Series in Law and Society (Oxford; Hart Pub, 2005).

Bourdieu, Pierre. The Social Structures of the Economy (Cambridge, Malden, MA: Polity, 2005). 
CNN Indonesia. “Gubernur Jateng Bela PB Djarum Gelar Audisi”, online: CNN Indonesia <https://www.cnnindonesia.com/olahraga/ 20190909 153045-170-428802/gubernur-jateng-bela-pb-djarum-gelar-audisi >

Erlangga Djumena. "Secercah Asa di Tengah Ancaman Resesi Halaman all”, online: Kompas.com <https://money.kompas.com/read/2020/04/ 25/211100526/secercah-asa-di-tengah-ancaman-resesi>.

Fauzi, Ridwan et al. Hubungan Terpaan Iklan, Promosi, Sponsor Rokok dengan Status Merokok di Indonesia (Jakarta: Tobacco Control Support Center \& IAKMI, 2019).

Gramsci, Antonio. Quintin Hoare \& Geoffrey Nowell-Smith. Selections from the Prison Notebooks of Antonio Gramsci (London: Lawrence \& Wishart, 1971).

Holzer, Boris. Moralizing the Corporation: Transnational Activism and Corporate Accountability (Cheltenham, Northampton, MA: Edward Elgar, 2010).

Hirschhorn, N. "Corporate Social Responsibility and the Tobacco Industry: Hope or hype?” (2004) 13:4 Tobacco Control 447-453.

Hurt, Richard D et al. "Roadmap To A Tobacco Epidemic: Transnational Tobacco Companies Invade Indonesia” (2012) 21:3 Tob Control 306312.

Indonesian House of Representatives. Naskah Akademik RUU Pertembakauan (Jakarta: Pusat Studi Hukum dan Kebijakan, 2016).

Indonesian Ministry of Industry. "Gambaran Umum Industri Rokok", online: Kementerian Perindustrian <https://www.kemenperin.go.id/ gambaran-umum-industri-rokok.php>.

Indonesian Ministry of Industry. "Kemenperin: Kontribusi Besar Industri Hasil Tembakau Bagi Ekonomi Nasional", online: Kementerian Perindustrian RI <https://kemenperin.go.id/artikel/17257/KontribusiBesar-Industri-Hasil-Tembakau-Bagi-Ekonomi-Nasional>.

Indonesian Statistics Bureau. Profil Kemiskinan di Indonesia Tahun 2019, No. 56/07/Th.XXII (Jakarta: Badan Pusat Statistik, 2020). 
Jakarta Globe. "In Its Defense of Kretek as Cultural Heritage, House Warns of 'Foreign Claims," online: Jakarta Globe <https://jakartaglobe.id/ news/defense-kretek-cultural-heritage-house-warns-foreign-claims $>$.

Jayani, Dwi Hadya. "Tren Kenaikan Cukai Rokok, 2020 Catat Kenaikan Tertinggi”, online: Databoks <https://databoks.katadata.co.id/data publish/2019/09/16/tren-kenaikan-cukai-rokok-2020-catatkenaikan-tertinggi>.

McDaniel, Patricia A \& Ruth E Malone. "What Is Our Story? Philip Morris's Changing Corporate Narrative" (2015) 105:10 Am J Public Health e68-e75.

Nichter, $\mathrm{M}$ et al. "Reading Culture from Tobacco Advertisements in Indonesia" (2009) 18:2 Tobacco Control 98-107.

Nurhasim, Ahmad. "183 Negara Setuju FCTC, Jokowi: Indonesia Jangan Ikut-ikutan", (14 June 2016), online: Tempo <https://nasional.tempo. co/read/779728/183-negara-setuju-fctc-jokowi-indonesia-janganikut-ikutan>.

Palazzo, Guido \& Ulf Richter. "CSR Business as Usual? The Case of the Tobacco Industry” (2005) 61:4 J Bus Ethics 387-401.

Patanavanich, Roengrudee \& Stanton A Glantz. "Smoking Is Associated With COVID-19 Progression: A Meta-analysis" (2020) 22:9 Nicotine Tob Res 1653-1656.

Putra, Afdal Makuragga. “Aku Merokok Maka Aku Berpetualang: Konstruksi Pesan dan Resepsi Khalayak Terhadap Iklan-Iklan Rokok Djarum Super Versi Petualangan" in Bunga Rampai Ilmu Komunikasi (Yogyakarta: Litera Press, 2017) 225.

Rosser, Andrew. "Contesting Tobacco-Control Policy in Indonesia" (2015) 47:1 Critical Asian Studies 69-93.

Tandilittin, Harsman \& Christoph Luetge. "CSR Activity of Tobacco Companies in Indonesia: Is it a genuine social responsibility?" (2015) 11 OJHE, online: <http://aquila.usm.edu/ojhe/vol11/iss1/3>. 
The Jakarta Post. "Smokers in Indonesia are at high risk for COVID-19': WHO", online: The Jakarta Post <https://www.thejakartapost.com/ life/2020/03/14/smokers-in-indonesia-are-at-high-risk-for-covid-19who.html>.

Tirto.id. "Audisi PB Djarum Pamit dan Kronologi Polemik yang Picu Teguran KPAI", online: tirto.id <https://tirto.id/audisi-pb-djarumpamit-dan-kronologi-polemik-yang-picu-teguran-kpai-ehHL>.

Urban Dictionary. "Urban Dictionary: Corporate Hegemony," online: Urban Dictionary <https://www.urbandictionary.com/define.php? term $=$ corporate $\% 20$ hegemony $>$.

World Health Organization. "Tobacco Industry and Corporate Social Responsibility an Inherent Contradiction" (2004) (WHO Tobacco Control Papers), online: <https://escholarship.org/uc/item/6kf7q7v9>. 